\title{
THE EMBRYOGENY OF SOME CUBAN NYMPHAEACEAE.
}

\author{
MELVILIE THURSTON COOK.
}

(WITH PLATES XVI-XVIII.)

THE taxonomic position of the Nymphaeaceae has always been somewhat doubtful. The anatomy of these plants is more nearly that of the monocotyledons, while the venation of the leaves would indicate that they are dicotyledons. A few years ago researches in this family were stimulated by Lyon's studies $(\mathbf{r} 7, \mathbf{1 8})$ on the embryogeny of Nelumbo, in which he came to the conclusion that they should be classified among the monocotyledonous families in the series Helobiae. Lyon's views were strengthened by my own paper on the embryogeny of Castalia odorata and Nymphaea advena (7), by ScHAFFNER's paper on morphological peculiarities of the Nymphaeaceae and Helobiae (26), and by York's embryological studies on Nelumbo (28). But Conard $(\mathbf{5}, \mathbf{6})$ in his studies in this same family took exceptions to this view, and holds to the idea that they should be classified among the dicotyledons. More recently, Motrier (20) has declared his belief that they are anomalous dicotyledons. However, he does not claim to have made any study of the Nymphaeaceae, but confines his studies to well recognized dicotyledonous species.

Immediately following Lyon's paper (18) on the embryogeny of Nelumbo, CAmpbell (4) raised the question as to whether other genera of the Nymphaeaceae might not also be monocotyledonous, and called attention to the fact that the structure of the flowers and character and arrangement of the vascular bundles in Cabomba and Brasenia were very similar to some of the Alismales; also "that the form of the leaves is often very suggestive of the sagittate leaves of Alisma or Sagittaria."

In consideration of the differences of opinion indicated above the writer accepted an opportunity to make a study of certain tropical species, hoping that additional light might be thrown on this very interesting family.

SchAFFNeR (26) called attention to the fact that it is in reality much easier to read monocotyledonous than dicotyledonous characBotanical Gazette, vol. 42] 
ters into the flowers; that while the genus Castalia has been described as having four sepals, $C$. odorata usually has only three, though sometimes by an expansion of the receptacle one segment of the second cycle is more or less exposed, while in $C$. tuberosa the displacement is normal. This led me to make a similar study of $C$. pubescens. In this species I found that 80 per cent. have the first segment of the second cycle exposed, while 20 per cent. have the second segment of the second cycle more or less exposed, thus showing five parts. SCHAFFNER also called attention to certain other secondary resemblances, such as number and arrangement of ovules and ovularies, between the Nymphaeaceae and well-recognized monocotyledonous plants.

The vascular bundles of all the species referred to in this paper were also studied, but gave no facts other than those already wellknown, the bundles in all cases being of the well-recognized closed type and arranged in the stems after the usual manner of this family.

On account of the large amount of gummy substance surrounding the ovules, considerable difficulty was experienced in getting a killing fluid to penetrate. This was especially true for Brasenia purpurea where the gummy substance was most abundant. Picric-acetic solutions proved to be the best fixing agents, while chrom-acetic and the Flemming's solutions were unsatisfactory and could be used only for the development of the embryo sac and the stamens.

\section{THE EMBRYO SAC.}

The formation of the embryo sacs in all genera is very similar, and in fact practically the same as described in my first paper (7). I will not give a discussion of each, therefore, but will give a general outline and present a series of figures illustrating the more important points, with special attention to the mature sac and the changes at the time of fertilization and immediately following.

The archesporial cell develops from the hypodermis (fig. II) and is easily recognized. An indefinite number of tapetal cells, usually varying from four to eight, are then produced. Three or four megaspores are then formed. The four may be produced either by a regular division of the mother cell into four cells; or occasionally by the division of the mother cell into three cells, followed by a division of the middle one (fig. 2). 
The innermost megaspore is functional and develops rapidly into the embryo sac at the expense of the other megaspores and the tapetal cells. This enlarged cell ( fig. 3) now touches the epidermis at the micropyle and passes rapidly through the two-, four-, and eightnucleate stages. - The mature embryo sac is very small and straight, and the enlargement is principally in the direction of the long axis of the ovule. Starch is usually very abundant and persists throughout the two- and four-nucleate stages; and in Brasenia purpurea and Cabomba piauhiensis usually throughout the eight-nucleate stage. It gradually disappears, first from the micropylar end.of the sac and finally from the antipodal end ( fig. 6 ). It probably undergoes modification to form the first food for the development of the embryo and endosperm.

Occasionally two embryo sacs were produced, but one was always absorbed by the other (fig. 7). This was more frequent in Cabomba piauhiensis than in any other species studied. Fertilization occurs almost immediately upon the completion of the eight-nucleate stage of the sac. The same very pronounced sclerification of the inner part of the epidermal cells ( $f g .4$ ), previously observed by me (7) for Castalia odorata, was observed in the tropical species of Castalia studied, but not in the other genera. The actual penetration of this epidermal wall by the pollen tube was observed in only a few cases. In fertilization the pollen tube ( $f g .4$ ) enlarged and stained so deeply that it was impossible to observe what fusion of nuclei did occur. At the time of fertilization the polar nuclei are very large, usually rather indistinct, and unite at the micropylar end of the sac just below the egg apparatus. At the same time the antipodals, which are very inconspicuous, undergo degeneration ( fig. 4). The synergids may persist a short time after fertilization ( $f i g s .5,6,7$ ), but usually disappear very quickly. They are most persistent in Cabomba piauhiensis.

The primary endosperm nucleus, which is now very large and conspicuous, moves to the antidopal end of the sac (figs. 5, 6), where it divides (figs. 7, 8, 20), and a very delicate wall is formed across the sac between the two daughter nuclei. This wall can be observed without great difficulty in Nymphaea advena (fig. 8) and in Castalia ampla (fig. 20), but is very difficult to see in the other species studied. 
The nucleus next to the embryo divides repeatedly, thus forming the endosperm which will be described later. The nucleus in the antipodal end acts slightly differently in the different species and will hereafter be designated the nucleus of the nucellar tube.

In Nymphaea advena a long tube-like extension of the sac is now formed through the nucellus, beginning with the antipodal end of the sac and extending to the chalazal end of the ovule. The very large and conspicuous daughter nucleus of the antipodal end, formed by the division of the endosperm nucleus, enters this tube, which will be called the nucellar tube, and travels to the chalazal end of the ovule, where it undergoes disintegration (figs. 8, I2, I3, I4). When the embryo is in the two-celled stage, the tube and nucleus have traveled about two-thirds the length of the ovule (figs. 8, I2); and when the embryo has reached the quadrant or octant stage, the tube is complete (figs. $13 a, 13 b$ ). In one case only ( fig. I $3 b$ ) the tube nucleus had divided. After this time it disintegrates (fig. I4). In its early development the tube is filled with protoplasm which to all appearances is traveling towards the embryo sac. This is exactly the condition observed by me in Nymphaea advena and Castalia odorata and described in my first paper (7).

In Castalia ampla (fig. 20) the nucellar tube is a short thick sac which is separated from the embryo sac by a constriction and by a thin wall, and which contains a very large nucleus and a large amount of protoplasm. As the embryo increases in size, the embryo sac enlarges, encroaching upon this nucellar tube sac and absorbing its contents (fig. 2I). The formation of this tube sac is very similar to that described by JoHnson (I2) for Saururus cernuus, except that in that species the tube sac is relatively larger and persists in the mature seed.

In Castalia pubescens the nucellar tube is much slower in development, much less conspicuous, and apparently of much less importance than in any of the other species studied. Extending from the antipodal end of the sac to the chalazal end of the ovule is a great mass of elongated cells (fig. 24) which are much richer in protoplasmic contents than the other cells of the nucleus. The greater part of this mass of cells disintegrates slowly and thus is formed a small tube reaching usually not more than one-half the length of the ovule 
(fig. $9^{a}$ ). The tube is flat $(f i g ., b)$ instead of cylindrical as in the case of the other species. This tube is usually completed just before the appearance of the cotyledonary ridge of the embryo. The nucleus was observed in the antipodal end of this tube but apparently disintegrated, and did not pass to the opposite end of the tube as in the case of the other species.

In Brasenia purpurea and Cabomba piauhiensis, the nucellar tube is long but very small. There is a rapid disintegration of the nucellar tissue to form the tube before the tube nucleus begins its passage. The tube nucleus gradually disintegrates, and has entirely disappeared before it reaches the chalazal end of the tube (figs. 7, Io, II); the chalazal end of the tube is considerably enlarged, is not so definite in outline as in Nymphaea advena, and contains fragments of the cell walls ( $f g . . I I)$.

In my previous discussion (7) I called attention to the fact that the behavior of the endosperm nucleus is similar to that of Sagittaria variabilis as described by SCHAFFNER (25), except that in S. variabilis there is no nucellar tube elongation; also, that judging from the studies of Wiegand (27) and Holferty (I0) on Potamogeton it is possible that a similar condition may be found in that genus.

Since that time, HALL (9), in his studies on Limnocharis emarginata, in which he finds a single polar nucleus, says:

The upper polar nucleus, when it has approached the antipodal end of the sac, divides transversely. The lower daughter nucleus remains in the position of its formation, being cut off by a wall across the sac and forming a large cell which does not divide further, but finally disappears through the encroachment of the endosperm. .... . The upper daughter nucleus travels back towards the egg apparatus, and by its further division forms the endosperm.

STRASBURGer (23) describes a similar action of the endosperm nucleus of Ceratophyllum submersum, in which, after the first division, the nucleus in the antipodal end of the sac does not divide, while the nucleus of the micropylar end forms the endosperm.

CAMPBell (I) in his discussion of Naias flexilis and Zannichellia palustris describes a condition which further study may prove to be similar to the Nymphaeaceae. In discussing Naias he says:

A peculiarity noted, which was also observed in Zannichellia, was the presence of a single large nucleus close to the antipodals, which was conspicuous at an early period and behaved much like the nucleus of the suspensor. Whether this 
was the lower polar nucleus or one of the two endosperm nuclei resulting from the first division of the primary endosperm nucleus could not be determined. Whichever is the case, it never divides, and all the endosperm nuclei arise from the division of the other primary endosperm (or polar) nucleus. The endosperm is limited, there being usually no trace of cell formation.

In discussing Zannichellia palustris he says:

As in Naias, there is evident soon after fertilization a large nucleus just above the antipodal cells, which undergoes no division, but increases very much in size. This is more variable in size than in Naias; not infrequently it could not be detected in the later stages, and in several instances it looked as if it were undergoing disintegration.

Previous to this time, JoHnson (I2) had published his studies on Saururus cernuus, in which he described a division and behavior of the endosperm nucleus very similar to what I described for Nymphaeaceae, and the formation of a nucellar tube sac intermediate between what I have described in this paper for Nymphaea advena(?) and Castalia ampla. JoHnson (I5) has since called attention to other genera of the Saururaceae (Anemiopsis and Houttuynia) which possess this character.

In my previous discussion of this subject (7), I expressed the opinion that the physiological significance of this nucellar tube and nucleus presented a very interesting problem, which should be considered in connection with the function of the antipodals. I called attention to the fact that in Ranunculaceae, Sparganium, and Vaillantia the antipodals appeared to furnish nourishment for the embryo; that the peculiar haustorial development of the antipodals of Vaillantia, the enlargement of the lower antipodal in Aster, the accumulation of endosperm in the antipodal region of Alyssum, and the large lower nucleus formed by a division of the endosperm nucleus (nucellar tube nucleus) in Sagittaria and the Nymphaeaceae showed a resemblance which $I$ believed to indicate a similar physiological function. At about the same time IKEDA (II) published the results of his studies on the physiological functions of the antipodals, in which he demonstrated by microchemical observations that the antipodals of Liliaceae possessed very important physiological functions.

JoHnson (14) also considers the antipodals of considerable physiological importance in certain of the Piperaceae, in which he describes them as increasing in size and sometimes in number. It 
seems very evident that this nucellar tube and its nucleus, which has common origin with the endosperm nuclei, are important structures for supplying food to the embryo through the agency of the endosperm. In Castalia pubescens, where the tube is developed, the same function is performed, first by the axial core of elongated cells (fig. 24) and later by the small nucellar tube ( $f g .9)$.

YORK (28) in his studies on Nelumbo did not observe the formation of a nucellar tube with its nucleus, but claims that both nuclei formed by the first division of the primary endosperm nucleus divided repeatedly. However, it may be that YoRK failed to observe the first division of this endosperm nucleus, that the tube nucleus disintegrates very quickly as in Castalia pubescens, and that he really observed the secondary divisions of the daughter endosperm nucleus in the micropylar end of the sac.

\section{ENDOSPERM.}

The development of the endosperm in this family presents two distinct types, Nymphaea, Castalia, and Nelumbo illustrating one, and Brasenia and Cabomba the other. The first type shows the formation of cell walls, that is, a cellular endosperm throughout its entire development; while the second type forms cell walls only in the latter part of its development. The formation of the two types of endosperm by closely related plants has been noted by several investigators.

In the first type the first cell walls are formed across the sac (figs. I3a, 20, 23), but gradually become more irregular and extend in various planes (figs. 2I, 24, 25). At first the cells contain considerable protoplasm and the entire endosperm is very active, but in a short time it seems to have reached its maximum activity and importance: In Castalia pubescens, at about the time and following the appearance of the cotyledonary ridge, the endosperm cells immediately over the plumule show a marked difference from the surrounding cells $(f i g . g a, x)$. They are slightly smaller, more delicate, and are probably the cells which give nourishment directly to the embryo. In this same species the endosperm may penetrate the antipodal end of the nucellar tube a short distance (fig. 23).

In the second type, represented by Brasenia and Cabomba, the 
protoplasm is very dense and the cells at first divide rapidly, but no cell walls are formed (figs. $10,33 b$ ). After the embryo has passed the stage indicated in fig. 34, the endosperm appears to become thinner and does not stain readily until the embryo is near maturity. The protoplasm then becomes very dense, cell walls are formed, and one layer (occasionally two or three in Brasenia) of cells is developed which completely surrounds the embryo (fig. 4o). This endosperm is usually thicker and forms two or more layers in a zone around the embryo at the point of origin of the cotyledonary lobes ( fig. $38, x$ ), and are very thin just below the root tip $(f i g .38, y)$. It appears that the endosperm in Brasenia and Cabomba must perform a more important function in the germination of the embryo than in the species of the other genera.

JoHnson (I4) in his studies on Piperaceae has expressed the opinion that the "embryo sporophyte of the second generation is never nourished by the parent sporophyte directly, but always through the intermediate gametophyte." The development and action of the endosperm in Nymphaeaceae confirms JoHnson's conclusions.

In all species studied there is a pronounced lateral enlargement of the embryo sac, at the expense of the nucellus, to accommodate the increasing endosperm and growing embryo (compare figs. 24 and 25).

\section{EMBRYO.}

The development of the embryo shows a very wide range of variation. The embryo of Nymphaea advena (?) of Cuba follows almost exactly the same course as previously described by the writer for Nymphaea advena of the northern United States. The fertilized egg first divides transversely ( $f g$. I2), and then two longitudinal walls result in a spherical embryo of eight cells. Successive cell divisions occur, but the spherical character is retained for some time, after which there is an excessive growth on the side next to the micropyle, forming a suspensor by which the embryo is attached to the nucellus, and a flattening on the opposite side, thus giving the embryo the shape. of a short blunt cone, or rather of a pear (fig. I6). In this respect it differs from $N$. advena of the north, in which the suspensor is much more rudimentary and does not develop until much later. At this 
time it somewhat resembles the embryo of Sparganium simplex as described by CAMPBELl (3); but without the younger stages of $S$. simplex and more of the young stages of $N$. advena (?) it is impossible to say whether this resemblance is more than superficial. From the large end of this conical embryo a cotyledonary ridge is now produced which extends almost entirely around this end and almost completely encloses the plumule (fig. I7), while in $N$. advena of the north it extends only a little more than half the distance around the embryo. This monocotyledonous character is very evident in embryos dissected out of the sacs. Two cotyledonary lobes are next developed from this cotyledonary ridge, thus giving it the dicotyledonous character (fig. I8). The development of this dicotyledonous character is much earlier and much more pronounced than in $N$. advena of the north. A number of embryos were cross sectioned and examined very carefully and considerable variation was found in the prominence of this character. In one case it was so great as to give the appearance of two equal cotyledons ( $f g$. I $g$ ). The development is strikingly similar to that of Nelumbo as described by Lyon (I8) and YORK (28).

SCHAFFNER (26) dissected the advanced embryos of $N$. advena out of the sacs and clearly demonstrated the formation of the two cotyledonary lobes. He did not contradict my conclusions, as stated by MotTIER (20), but made his studies from older embryos than I was able to secure at the time my studies were made.

The embryos of the two species of Castalia show some differences and also differ from Castalia odorata. In Castalia ampla a proembryo is formed which may consist of as many as six cells in linear arrangement (figs. 20,2I). The terminal cell then divides by a longitudinal wall, which is followed by a similar division in the next cell (fig. 2I). The four cells thus formed then divide by a second longitudinal wall at right angles to the first. By repeated division, this mass of cells now forms a spherical embryo supported by a suspensor of four or five cells in linear arrangement ( $f g .22)$. One or more of these suspensor cells, usually the basal, may divide longitudinally. On account of the seed pods sinking soon after fertilization it was impossible to follow the development in this species further.

In Castalia pubescens the embryo develops in the same manner, 
except that there are usually not more than four cells in the proembryo. With the formation of the spherical embryo the suspensor increases in diameter and the cells usually divide longitudinally (figs. 24, 25, 26). After the spherical stage the embryo gradually assumes a pear-shape, and a little later develops the collar-like ridge which extends about two-thirds around the embryo at its greatest circumference. This condition was readily demonstrated by two series of longitudinal sections cut at right angles to each other and a series of cross sections (figs. 27-30). Fig. 27 is from a longitudinal section passing through the middle $(x)$ and between the two points of the crescent-shaped cotyledonary ridge (y). Fig. 28 is from a longitudinal section at right angles to fig. 27 and passes through the cotyledonary ridge near the points of the crescent $(z)$. Fig. 29 is from a series of cross sections of an embryo of corresponding age to figs. 27 and 28. Fig. 30 is from section $d$ of fig. 29, i. e. at about the point where the cotyledonary ridge arises. Fig. $3^{I}$ is reconstructed from a series of sections of a slightly older embryo. At this time there was no external indication of the two cotyledonary lobes, but the rapid division of cells just within the points of the crescent-shaped cotyledonary ridge (fig. $30 \mathrm{C}, \mathrm{I}$ ) indicates their early formation.

It was impossible to follow the development of the embryo beyond this point, because of the withdrawal of the seed pods from the surface of the water to the bottom, where they were quickly buried in the mud. This withdrawal commenced soon after pollination and was accomplished by the spiral-like formation of the peduncle which gradually contracts. However, Schaffner (26) was able to dissect the young embryos of Castalia odorata out of their sacs and makes the following statement concerning them:

Although the "dicotyl" appearance is quite strong, the embryo must be regarded as the same type as Nymphaea and Nelumbo. In the very young embryo there is an expansion which extends nearly around the base but is discontinuous at one side. Soon this expansion develops on opposite sides as two prominent lobes in such a manner that the original connection between the two lobes is very difficult to distinguish. On examining the embryo from below, however, similarity to the Nelumbo and Nymphaea embryos becomes perfectly apparent. There is the same opening on one side, and on the back a connection of the two lobes, only to a less extent. Unless special care were taken in recon- 
structing such an embryo from serial sections, one might readily take it for a dicotyl. It will be evident, however, from a comparison of the figures that the Castalia embryo represents only the extreme of the lobing shown in Nelumbo and Nymphaea.

The formation of the suspensor is entirely different from what I observed in $C$. odorata, but corresponds with ConaRD's $(\mathbf{5}, \mathbf{6})$ observations. The suspensor disappears soon after the formation of the cotyledonary ridge.

The development of the embryos of Brasenia purpurea and Cabomba piauhiensis is practically the same, but since $C$. piauhiensis is much more easily sectioned and furnished much better preparations, most of the drawings were made from it. The fertilized egg divides by the formation of cross walls and produces a proembryo of three or four cells in linear arrangement (figs. 32, 33a, 34, 35). The terminal cell then divides, forming a quadrant ( fig. $33 a$ ), then it forms the octant, and then a large spherical embryo supported by a short suspensor of two or three cells which usually divide longitudinally (figs. 34, 35, 36). As the embryo increases in size, it becomes more or less flattened against the walls of the sac and develops the cotyledonary ridge ( $f g .36, x$ ) similar to the two genera just described, except that this ridge extends almost entirely around the plumule, thus forming a pit with the plumule in the center. The dicotyledonous character produced by the development of the cotyledonary lobes appears very early. Only by the most careful examination of the intermediate stages at the time of the first appearance of the cotyledons, and by the most careful cross sections was it possible to demonstrate the common origin of these two cotyledonary lobes. They develop very early and the edges and tips come together, thus enclosing the plumule in a short, hollow cone ( $f i g$. 37). After this the development of the embryo is a mere increase in size (figs. 38,39 ), accompanied by the modification of the endosperm previously referred to. The suspensor persists until the embryo is almost mature and then disintegrates.

It will be noted that the young embryo of Nymphaea advena (?) is similar to the embryos of Lysichiton kamtschatense as described by Campbell (2); and of Ceratophyllum submersum as described by Strasburger (23). The young embryos of Castalia ampla, C. 
pubescens, Brasenia purpurea, and Cabomba piauhiensis all have the same general character as Nymphaea advena, except that they possess suspensors. They also show some resemblance (which may be superficial) to the embryo of Sparganium simplex as described by Campbell (3). They also resemble the embryos of Naias flexilis and Zannichella palustris as described by CAMPBell (I), Potamogeton foliosus and P. natans as described by WiEgand (27) and HoLFERTY (IO), and Limnocharis emarginata as described by HALL (9) except that they do not possess the large basal cell of the suspensor. The late development of the suspensor in Nymphaea advena (?) of Cuba and $N$. advena of the north, as previously described by me, may confirm in some measure Coulter and Chamberlain's view that the Alisma-type of monocotyledonous embryo is primitive and that the suspensor in the Pistia type has been suppressed.

It will also be noted that the origin of the cotyledonary lobes in all cases is from a crescent-shaped cotyledonary ridge about the larger part of the embryo, and that my results coincide with the conclusions reached by Lyon, SchaffNer, and York. This point in ConARD's studies is illustrated by a single figure $(48, d)$ of Castalia caerulea. This figure agrees exactly with fig. 30 and text fig. $2, d, e$ of my first paper, with Lyon's fig. Io, and York's fig. 33 of Nelumbo. However, my figures are parts of series which illustrate the true monocotyledonous character of the embryo; and this monocotyledonous character of $C$. odorata was afterwards demonstrated by SchaffNer who dissected the embryos out of their sacs.

RICHARD (2I) referred to the embryos of the grasses, Nelumbo, Ruppia, Hydrocharis, and Zostera as embryons macropodes, and SCHAFFNER (26) confirms this view and expresses the opinion that the massive expansion and lobes of Halophila, Ruppia, Zostera, Nelumbo, Nymphaea, and Castalia are not homologous with the cotyledons, but are specially developed absorbing organs.

The figures of this paper show a striking resemblance to the figures of anomalous dicotyledons by LEwIs (I6) and MotTIER (20). However, the flowers show more monocotyledonous than dicotyledonous characters, while only the leaves may be considered as uniformly presenting dicotyledonous characters. It appears, therefore, that the Nymphaeaceae can be more properly classed as 
anomalous monocotyledons, rather than as anomalous dicotyledons as suggested by MotTiER.

\section{SUMMARY.}

I. The development of the embryo sac is practically the same in all species.

2. In all species the endosperm nucleus divides and the daughter nucleus in the antipodal end enters a nucellar tube or sac which penetrates the nucellus.

3. This nucellar tube or sac is apparently for the purpose of transferring food from the nucellus to the endosperm, from which it is transferred to the embryo.

4. The endosperm is of two types: the cellular in Nymphaea and Castalia, and the nuclear followed by the cellular in Brasenia purpurea and Cabomba piauhiensis.

5. The character of the endosperm in the late stages of Brasenia purpurea and Cabomba piauhiensis indicates a greater importance in germination than in the other genera.

6. The embryo of Nymphaea advena(?) originates as a spherical mass of cells and later develops a cotyledonary ridge and suspensor, while the other species develop embryos consisting of a single row of cells, from which is formed a spherical embryo supported by a suspensor. A crescent-shaped cotyledonary ridge is then developed, ranging from two-thirds to almost the entire distance around the embryos.

7. With the development of the cotyledonary ridge, two cotyledonary lobes are produced which may readily be mistaken for two cotyledons.

Estación Central Agronomica,

Santiago de las Vegas, Cuba.

Note: The material from which these studies were made was submitted to specialists in taxonomy. There was some difference of opinion as to whether the Nymphaea was a large-leaved form of $N$. advena or another closely related species. Castalia pubescens is an introduced species from eastern India, Philippines, Java, and Australia. It was collected in a large lagoon near San Antonio de las Baños in Havana Province. Nymphaea advena(?) was collected in the river at San Cristobal and in a small lagoon south of Herredura in Pinar del Rio Province; all other species in this same small lagoon. Specimens of all these species have been deposited in the New York Botanical Garden. 


\section{LITERATURE CITED.}

I. Campbell, D. H., A morphological study of Naias and Zannichellia. Proc. Calif. Acad. Sci. III. I: I-62. pls. I-5. I897.

2. - Notes on the structure of the embryo sac in Sparganium and Lysichiton. Bot. Gazetre 27:153-166. pl. 26. I899.

3. Studies on the flower and embryo of Sparganium. Proc. Calif. Acad. Sci. III. I : 293-328. pls. 46-48. I897.

4. On the affinities of certain anomalous dicoyledons. Amer. Nat. 36:7-12. figs. 2. 1902 .

5. Conard, H. S., Note on the embryo of Nymphaea. Science N. S. I5:316. 1902.

6. - The water lilies: a monograph of the genus Nymphaea. The Carnegie Institution of Washington, Publication No. 4. I905.

7 Cоoк, Mes. T., Development of the embryo sac and embryos of Castalia odorata and Nymphaea advena. Bull. Torr. Bot. Club 29:21 I-220. pls. I2-13. tgo2.

8. Coulter, J. M., and Chamberlain, C. J., Morphology of angiosperms. 1903 .

9. HaLr, J. G., An embryological study of Limnocharis emarginata. Bот. GaZETTE 33:214-219. pl. 9. 1902.

:o. Holferty, G. M., Ovules and embryo of Potamogeton natans. Bot. Gazette 31:339-346. pls. 2-3. I901.

II. IKEDA, T., Studies in the physiological functions of the antipodals and related phenomena of fertilization in Liliaceae. I. Trycirtis hirta. Coll. Agric. Imp. Univ. Tokyo 5:41-72. pls. 3-6. I902.

12. Johnson, D. S., On the development of Saururus cernuus. Bull. Torr. Bot. Club 27:365-372. pl. 23. I900.

13. - On the endosperm and embryo of Peperomia pellucida. Boт. GazeTte 30: I-II. pl. I. I900.

14. - On the development of certain Piperaceae. Bot. Gazette 34: 321-340. pls. 9-Jo. I902.

15. - Seed development in the Piperaceae and its bearing on the order. Johns Hopkins Univ. Circ. 178: 29-32. 1905.

16. LEwIS, C. E., Studies on some anomalous dicotyledonous plants. Bot. GaZETTE 37:127-138. pls. 7-8. 1904.

I7. Lyon, H. L., Preliminary note on the embryogeny of Nelumbo. Science N. S. 13:470. I901.

I8 Observations on the embryogeny of Nelumbo. Minn. Bot. Studies 2:643-655. pls. 48-50. 1901.

I9. - The embryo of the angiosperms. Amer. Nat. 39: 13-34. figs. II. 1905 .

20. MotTier, D. M., The embryology of some anomalous dicotyledons. Annals of Botany 19:447-463. pls. 26-27. 1905. 
21. Richard, L. C., Analyse botanique des embryons endorhizes ou monocotyledonés, et particulièrement de celui des Graminées. Annales Paris Mus. Nat. Hist. I7:223-251, 442-487. I8I I.

22. Sargent, Ethel, Evolution of the monocotyledons. Bot. Gazette 37: 325-345. figs. 6. I904.

23. Strasburger, E., Ein Beitrag zur Kenntniss von Ceratophyllum submersum und philogenetische Erörterungen. Jahrb. Wiss. Bot. 37:477-526. pls. 9-II. I902.

24. Schaffner, J. H., The embryo sac of Alisma Plantago. Bot. Gazette 21:123-132. pls. 9-IO. 1896.

25. - The life history of Sagittaria variabilis. Вот. Gazette 23:252-273. pls. 20-26. 1897 .

26. Some morphological peculiarities of the Nymphaeaceae and Helobiae. Ohio Nat. 4:83-92. pls. 5-7. I904.

27. Wiegand, K. M., The development of the embryo sac in some monocotyledonous plants. Вот. GazetTe 30:25-47. pls. 6-7. I900.

28. York, H. H., The embryo sac and embryo of Nelumbo. Ohio Nat. 4: 167I76. I904.

\section{EXPLANATION OF PLATES XVI-XVIII.}

Figures of the same relative value are drawn with the same lenses: figs. $I-7$ with Zeiss no. 4 oc. and $\frac{1}{12}$ obj.; figs. $12-16,20-28,30,32,36$, and 40 with no. 4 oc. and DD obj.; figs. 8-II, I7-I9, 29, 3I, 37-39 with no. 4 oc. and $\mathrm{A}$ obj.

\section{PLATE XVI}

Fig. I. Archesporial cell of Brasenia purpurea.

FIG. 2. Megaspores of Nymphaea advena (?).

FIG. 2. Uninucleate embryo sac of $N$. advena (?).

Fig. 4. Mature embryo sac of Castalia pubescens, showing entrance of pollen tube $(p t)$.

FIG. 5. Embryo sac of $C$. pubescens just after fertilization, showing fertilized egg (o), remains of synergids (syn), and the endosperm nucleus.

Fig. 6. Embryo sac of Brasenia purpurea just after fertilization, showing egg (o), synergid (syn), endosperm nucleus (end $n u)$, and starch in the antipodal end of the sac.

Fig. 7. Embryo sac of Cabomba piauhiensis, showing fertilized egg (o), the two synergids (syn), the endosperm nucleus (end $n u)$ after first division, and the remains of a second $\operatorname{sac}(e s)$.

Fig. 8. Embryo sac of $N$. advena (?), showing two-celled embryo, the nucellar tube, and the two daughter cells of the endosperm nucleus (en) separated by a wall; the tube is about three-fourths the length of the ovule.

FIG. 9a. Embryo sac of $C$. pubescens, showing large pear-shaped embryo with region of modified endosperm $(x)$, and the nucellar tube.

Fig. $9 b$. Cross-section of nucellar tube of $9 a$. 
Fig. Io. Embryo sac of $C$. piauhiensis, showing two-celled embryo and nucellar tube. The endosperm nucleus has divided and one daughter cell entered the tube $(n t n)$, while the other has remained in the sac and undergone first division (end).

Fig. II $a$. Embryo sac and mature nucellar tube of $C$. piauhiensis with spherical embryo; the thin endosperm filled the sac at this time.

FIg. II $b$. Cross-section of tube of $I I a$ at smallest part.

FIGS. I2-I9. Nymphaea advena(?).

FIG. I $2 a$. Two-celled embryo with daughter nucleus of endosperm nucleus (en) after first division; same as fig. 8.

Fig. I2b. Nucellar tube nucleus of figs. 8 and $12 a$.

PLATE XVII

FIG. I3a. Section of spherical embryo in octant stage surrounded by endosperm.

Fig. $13 b$. Lower part of the nucellar tube of $I 3 a$ in which the nucellar tube nucleus was divided.

Fig. I4. Mature nucellar tube nucleus.

Fig. I5. Spherical embryo.

FIG. I6. Pear-shaped embryo at time of origin of cotyledonary ridge and with well-developed suspensor.

FIG. I7. Cross-section of embryo a little older than that in fig 16 .

FIG. I8. Cross-section of embryo older than that in fig. 17 , showing monocot character in lower part and dicot character in upper part; $3 \mathrm{~d}$, 4th, 6th, I4th, Igth, and 24th sections.

FIG. I9. Cross-section of embryo showing equal cotyledonary lobes (dicot characters); Ist, 4th, 5 th, 7 th, 8 th, and I 5 th sections.

Figs. 20-22. Castalia ampla.

Fig. 20. Embryo sac and two-celled embryo showing endosperm and nucellar tube nucleus $(n t n)$ in sac-like nucellar tube.

FIG. 2I. Older stage of same, showing absorption of nucellar tube and nucleus $(n t n)$ by endosperm.

FIG. 22. Spherical embryo with suspensor.

\section{PLATE XVIII}

\section{Figs. 23-31. Castalia pubescens.}

Fig. 23. Two-celled embryo and endosperm; the endosperm has penetrated the upper part of the nucellar tube.

Frg. 24. Spherical embryo with suspensor and endosperm, also showing elongated nucellus cells in axis of ovule below sac (enc).

FrG. 25. Older stages of the same showing enlargement of sac at right angles to the original long axis.

FIG. 26. Young pear-shaped embryo.

FIG. 27. Longitudinal section of embryo passing through middle of crescentshaped cotyledonary ridge $(x)$ and between the points of the same $(y)$. 
FIG. 28. Longitudinal section at right angles to fig. 27 passing through the cotyledonary ridge $(z z)$ near the points of the crescent.

FIG. 29. Cross sections of embryo at about same age as figs. 27 and 28 .

FIG. 30. Section $d$ of fig. 29; $c l$, cotyledonary lobes; other letters same as in figs. 27 and 28 .

FIG. 31. Reconstruction from sections of embryo a little older than those in figs. $27-30$.

$$
\text { FIGs. 32-40. Cabomba piauhiensis. }
$$

FIG. 32. Two-celled embryo.

FIG. 33a. Section of embryo in octant stage showing two-celled suspensor.

FIG. $33^{b}$. Endosperm of $33^{a}$.

Frg. 34. Spherical embryo with three-celled suspensor.

FIG. 35. Spherical embryo showing original two-celled suspensor subdivided by longitudinal divisions.

FIG. 36. Longitudinal section of embryo at about time of origin of cotyledonary ridge, showing two-celled suspensor; cut same direction and showing same points as fig. 27.

FIG. 37. Reconstruction from section of embryo slightly older than fig. 36 and showing early development of cotyledonary lobes.

FIG. 38. Reconstruction from sections of almost mature embryo; drawn to same scale as fig. 37 .

FIG. 39. Cross-sections of embryo; $2 \mathrm{~d}, 6 \mathrm{th}, 8 \mathrm{th}$, I2th, 24th, and 28 th sections.

FIG. 40. Endosperm from embryo near same age or little older than fig. 38 . 


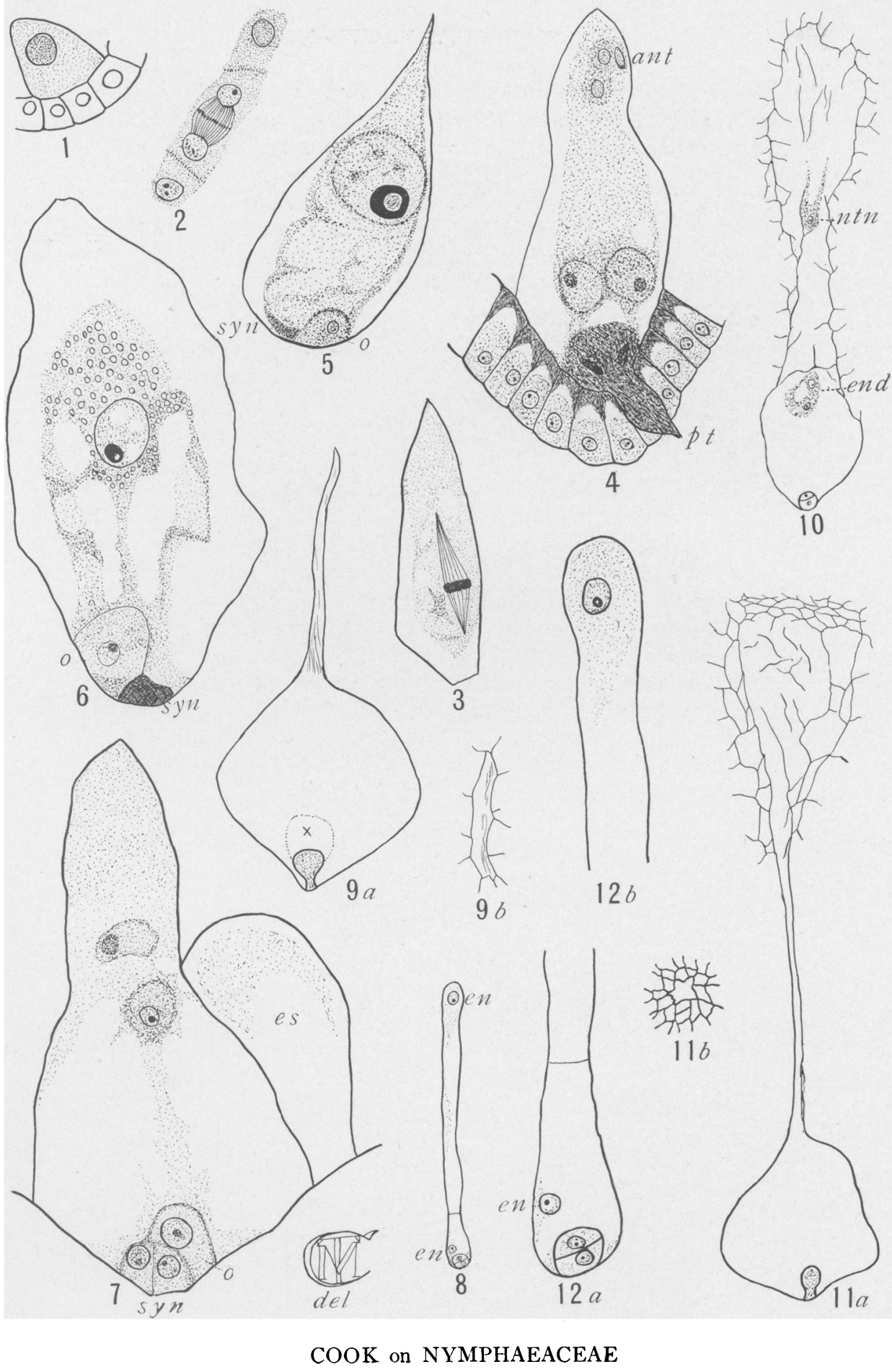

This content downloaded from 080.082.077.083 on February 19, 2018 18:18:58 PM All use subject to University of Chicago Press Terms and Conditions (http://www.journals.uchicago.edu/t-and-c). 


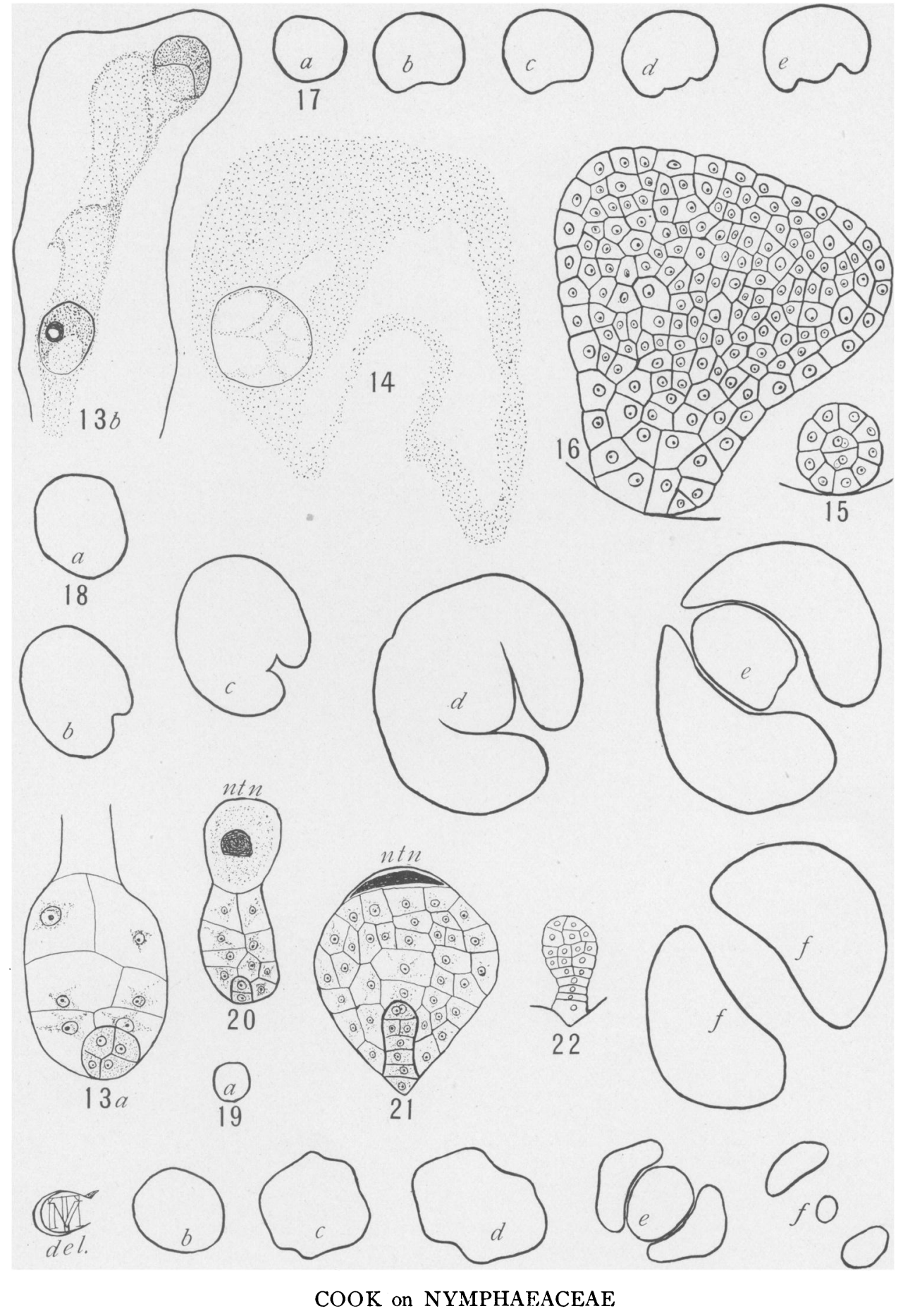

This content downloaded from 080.082.077.083 on February 19, 2018 18:18:58 PM All use subject to University of Chicago Press Terms and Conditions (http://www.journals.uchicago.edu/t-and-c). 


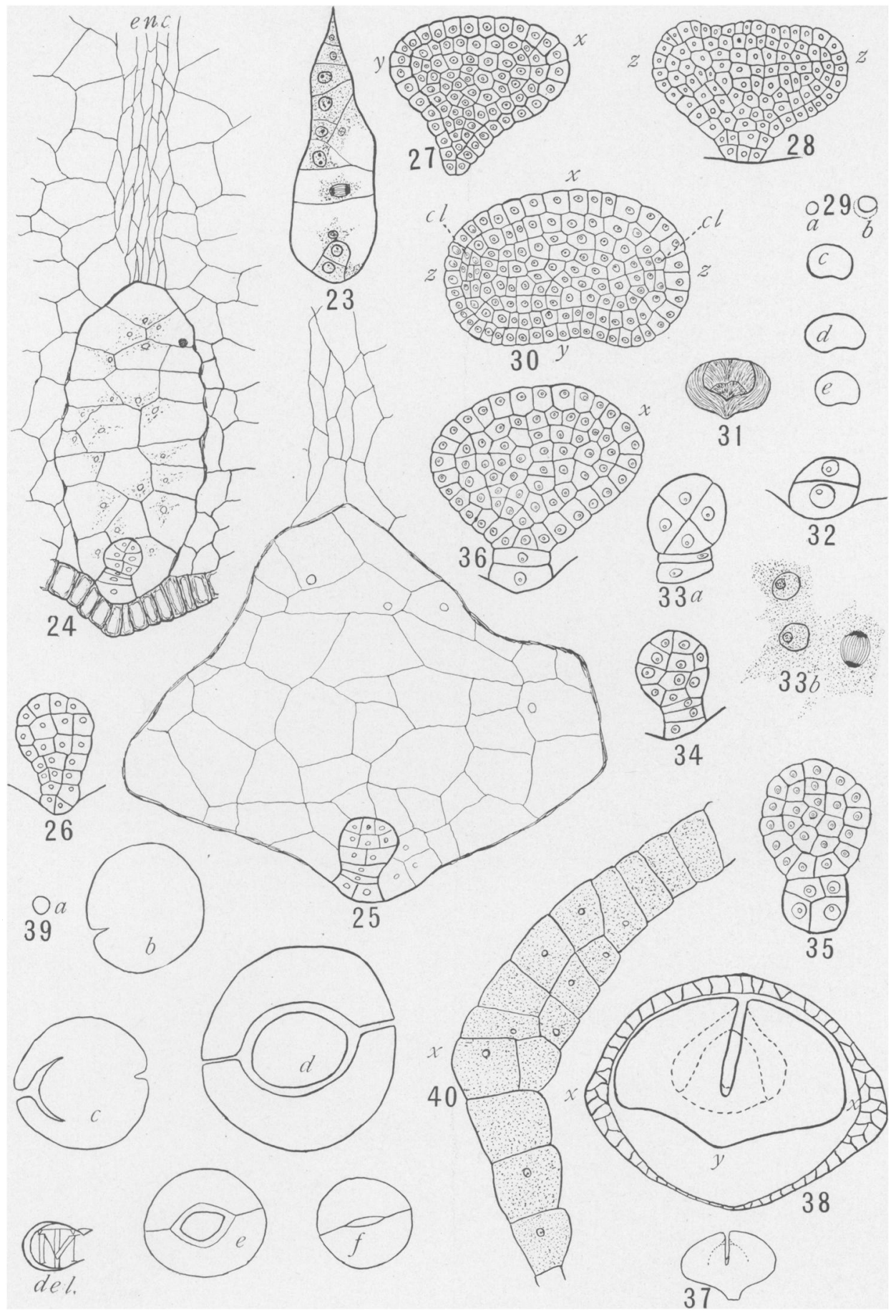

COOK on NYMPHAEACEAF.

This content downloaded from 080.082.077.083 on February 19, 2018 18:18:58 PM All use subject to University of Chicago Press Terms and Conditions (http://www.journals.uchicago.edu/t-and-c). 